\title{
HOW AND WHAT CHILDREN PLAY AT THE THRESHOLD OF THE THIRD MILLENNIUM
}

\author{
György KovÁcs-Éva BAKOSI \\ Wargha István College of Education \\ H-4220 Hajdúböszörmény, Désány I. u. 1-9, Hungary
}

Nowadays opinions on play at preschool are very controversial. If we raise the question whether teachers provide enough opportunities for play we can answer yes without hesitation: never before has been seen such a wide range of toys in preschools as nowadays. But if we consider children's everyday play and their interaction in play, the situation is not that simple, especially not in terms of play in the family at home.

Another way of raising the question is what preschool teachers think about children's play. The answers are very different in this regard, too. There are some teachers who think that children can hardly play when they are admitted to the preschool but soon due to the preschool and the teachers' help positive changes can be observed. Others are of utterly different opinion saying that despite every attempt there is little achievement. Some do not consider this a problem; they regard it as something natural because "the world has changed". "Life today does not favour play" - as one of the teachers asked in our survey said. We have even encountered such pessimistic opinions on play that question whether it is worth making efforts to promote play since children are interested in many other different things especially at the age of 5 to 7 . Although these extreme views are rare, they occur and expressed time after time nevertheless. The following statements, however, are heard a lot more frequently: "Children still need play but not role-play primarily". "Role-play is ancient history now." "Children do not know what to play because they do not have experiences." Some preschool teachers' observations seemingly verify these statements. Sometimes despite all the positive endeavours of preschool teachers role-play occurs very rarely. The reason why such statements are uttered here and there is not very difficult to find. These statements relate to children of 6 or more years of age, who are at a different stage of play from those of 3 to 5 years of age. Role-play has a different meaning for them. Instead of the decline in the need for role-play we should speak about the change in its patterns and about the contradiction between the desire for play and the opportunities for play. In preschools the conditions are usually not provided entirely for the new changed needs for play. Not everywhere and not always can teachers keep up with the changes by creating conditions for the new requirements and by attributing new features to old toys. The simultaneous occurrence of different toys, games and other activities may also be difficult to deal with. 
Table $1 / \mathrm{a}$

WHAT DO YOU LIKE TO PLAY BEST?

(children's answers)

\begin{tabular}{|c|c|}
\hline Boys & Girls \\
\hline \multicolumn{2}{|c|}{ alone } \\
\hline $\begin{array}{l}\text { 1. build - LEGO, TÜSI (a Hungarian brand name } \\
\text { of building blocks) }\end{array}$ & play with a doll, a Barbie \\
\hline 2. play with cars & visual activity \\
\hline 3. jigsaw puzzle & build - LEGO \\
\hline 4. visual type of play & role-play, dress up \\
\hline 5. play war, police & jigsaw puzzle \\
\hline Total: 29 types & Total: 20 types \\
\hline I don't like playing, I can't play: $8.4 \%$ & I don't like playing, I can't play: $6 \%$ \\
\hline \multicolumn{2}{|c|}{ with peers } \\
\hline 1. build & play mums and dads \\
\hline 2. play with cars & play cooking \\
\hline 3. play war, police, soldiers & visual activity \\
\hline 4. play in the sand & build - LEGO, TÜSI \\
\hline 5. games with movement (hide-and-seek, tag) & play tag, hide-and-seek \\
\hline Total: 34 types & Total: 30 types \\
\hline $7.2 \%$ did not specify & $7.3 \%$ did not specify \\
\hline
\end{tabular}

with an adult, with the preschool teacher

1. build

2. dominoes, tell tales, rhymes

3. board game, visual type of play

4. play cards

5. play football, with cars, fight, box, watch TV, video, play at horses

Total: 36 types

$6 \%$ do not play with parents board game, logical game, visual activity singing games

play with a doll

play cards, build, listen to tales

jigsaw puzzle, play at keeping shop

Total: 33 types

$8.8 \%$ do not play with parents

These changes represent a really existing problem. We are making an attempt to reveal how they are related to the exogenous, social changes.

This study is based on a representative survey carried out in the preschools of four Hungarian counties. We collected data from three groups concerned, i. e. preschool children, preschool teachers and parents. We observed children's play and after the analysis of the intentionally created educational situations, the records of children's play and the one-to-one interviews we compared them to the information 
Table $1 / \mathrm{b}$

WHAT DO CHILDREN LIKE TO PLAY BEST?

(children's answers, curiosities)

\begin{tabular}{lll}
\hline \multicolumn{1}{c}{ Boys } & \multicolumn{1}{c}{ Girls } \\
\hline \multirow{2}{*}{ Alone } & $\begin{array}{l}\text { play 'bank at the post office' } \\
\text { splash about } \\
\text { construction } \\
\text { play with robots }\end{array}$ & $\begin{array}{l}\text { suck dummy } \\
\text { watch TV } \\
\text { play in the street } \\
\text { drive a real car }\end{array}$ \\
& $\begin{array}{l}\text { listen to music } \\
\text { play on the computer } \\
\text { play 'bosses', pirates } \\
\text { catch the girls } \\
\text { play Simba } \\
\text { whatever the others want to play } \\
\text { hide-and-seek in the wardrobe } \\
\text { talk, walk, look at books } \\
\text { play tag, hide-and-seek } \\
\text { play on the computer } \\
\text { play clowns } \\
\text { play at the playground }\end{array}$ & $\begin{array}{l}\text { play war } \\
\text { scamper about, run about } \\
\text { play Simba }\end{array}$ \\
& $\begin{array}{l}\text { fight } \\
\text { play on the the computer } \\
\text { play and perform with puppets (1.4\%) } \\
\text { dance } \\
\text { role play: play at keeping shops, play } \\
\text { hairdressers, 'queen', play with dolls, } \\
\text { cook (for real, not for play) } \\
\text { play ball }\end{array}$ \\
\hline
\end{tabular}

gained from the questionnaires distributed among teachers and parents. The survey was aimed at exploring children's favourite play activities, their desire for play at home and at preschool. We endeavoured to collect the opinions of parents on the same topic, as well. The comparison provides valuable information in regard to how well adults know and understand children's play intentions and what sort of play communication exists between adults and children, while the children's desire for play provides us with information with regard to the direction of changes.

Originally the survey material (the questions) was distributed in 58 preschools and concerned 1450 preschool children and we received answers related to 941 preschool children from 51 groups. We processed data given by 47 preschool teachers. We carried out a survey with a multiple aim but we focused on the points related to our topic this time.

By way of introduction we refer only to a few data now as an explanation of our motive for writing this study. One of the related questions was what children like to play best at home. (Tables $1 / \mathrm{a}, 1 / \mathrm{b}$ ). We looked at play in relation to solitary play, play with peers/other children and play with adults. One of the most conspicuous data was the diversity of children's answers. The boys specified 29 types in the category of play alone/solitary play and the girls listed 20 . In the category of play with 
peers/other children (siblings, neighbour children) the boy specified 34 types and the girls 30, while in the category of play with adults the boys had 36 types and the girls 33. Thus the boys who took part in the survey specified 99 games and the girls 83 . These numbers are very large even if there is some overlap in the content of the games listed in the different categories.

One of the important characteristic features of the changes taking place at the threshold of the third millennium is the wide range of the forms of play along with their benefits and drawbacks. As a positive feature we can mention the appearance of the individual forms of play, the soaring of children's imagination in a freer way and the appearance of the social changes in children's play. As a negative feature we can mention the deficiency, and more often the total lack of conditions for play and also the fact that children scarcely specify play activities with longer duration other than play with cars and fighting games.

Certainly, there are other conclusions to be drawn from the data given in the questionnaires, which we intend to do in later chapters of this article. As an introduction perhaps it has been sufficient to indicate our intentions and to offer a brief overview of the changes in play as regards its form and content while referring to the possible reasons, as well, in order to promote children's play, to have a better understanding of its forms and to improve the conditions for children's play in preschools.

After raising the problem and giving its explanation, in our study we shall deal with the main features of the changes in society and play, and in the end we shall sum up the conclusions that can be drawn for preschools.

\section{EXPLANATION OF RAISING THE PROBLEM}

The 20th century can be rightfully called the century of play. By the turn of the 19th and the 20th century the psychological and educational significance of play had been justified. In the first decades of this century more and more disciplines began to find the role of play in children's lives (archeology, history of education, ethology, sociology, etc.) and what is more, play was used as a pedagogical aid in education. Play has become professionalized in this century. At present, studies searching the significance and meaning of play reach well beyond the boundaries of preschool age. These studies cover the whole of school age and, what is more, they prove the influence of play on the lives of adults as well in more and more different ways.

By the end of the 20th century a new question has been raised concerning play, namely: How can play fulfil its role in children's lives amid the complex changes taking place today? The merits of the question are enhanced further by the principle that underlies the fact that the more developed a society is the more important play is for children with respect to the perceiving and the processing of the accumulating and more and more complex stimuli.

The rapid change that play goes through reflects the turbulence of social achievements in itself. In order to avoid the damages to the nerves due to the rather 
intense social influences and the fast changes people need a calm and relaxing atmosphere. Play as a complex effect of appropriate conditions is able to serve this purpose. The changes that take place within play (within its motivational system, content and form of occurrence) modify our existing knowledge, considering either the parents' role or the functional changes of the objects and materials involved in play or children's playing habits. These changes, along with the educational and psychological achievements, draw our attention to some correlations that may not be neglected.

When dealing with the new features of play and toys later in this article we must not forget about either the durability of the basic principles defining the essence of play or about the forms of play just slightly influenced by the changes.

\section{SOCIAL CHANGES INFLUENCING PLAY}

1. The restructuring in society takes place in a very complex way both at macro and micro levels. It is not the process itself that is new and unusual - it being normal for a society - but its pace and size. Societies in their entirety - not only here in Hungary - are in a turbulent state. It takes time until the social processes become balanced and calm. This turbulent (accelerated) state of development determines the restructuring within play.

There is no time either to make a new type of play last long and deepen or not even to make it a tradition on the basis of the play of older age groups.

Certain well-known forms of play change continuously and grow richer with new elements and in the course of time they change completely in their aims, content and materials. At the same time other games lose their attraction and occur more and more rarely. Let us take playing at keeping shop as an example. Due to the changes of the last decades the youngest generation does not know about the humane atmosphere of the old type groceries or the informal relationship between the customer and the shop asssistant at all. By these days our shopping habits have undergone such enormous changes that they have lost their magic that used to give inspiration to play.

As a consequence of social changes well-known forms of play are becoming forgotten time after time or are becoming 'museum pieces'. The accelerated movement in our society makes this selection faster and broader than it has ever been known. Earlier generations were able to part gradually from the different forms of their play awaiting until these forms were replaced by new ones. Unfortunately, there is no transition; certain forms of play are getting lost without new ones taking their places. Forms of play imitating traditional trades provide lots of examples to verify this process. So the turbulent changes affect play, too.

In the meantime traditional playing habits are fading, groups of playing children are disappearing and it is hard for children to find new, appropriate and feasible forms of play. Children are losing their playmates (siblings and adults) because of the decrease in the number of big families and also the disintegration of extended 
families where more generations lived together. According to our survey, $14.8 \%$ of the children asked never play with their parents (Table 1). 10.7\% of the parents admit not playing with their children. These are stunning figures. During the two weeks of the survey $36 \%$ of the adults (parents, grandparents) played only once with their children, which makes the picture even more saddening. Time of collective play, spent together with children does not make you optimistic either. $28 \%$ of the adults asked in the survey play with their children no more than five to thirty minutes. Only $24 \%$ of all adults play with their children for over an hour.

2. The revolution of science and technology has made and still makes a multiple impact on play and playing habits. Partly because it has changed the proportion of physical work in production, and partly because the new working tools of production have opened new pathways before new forms of play. Decrease in manual work and its withdrawal from the children's everyday environment have significantly diminished both the opportunities and the forms of imitation.

The new influence of the revolution of technology can be experienced day after day, and it is especially true for electronics and microelectronics. Sometimes it is hard even for adults to understand the toys and the forms of play offered to children. Microelectronics, computers and mobile telephones represent new sources of play, raising play into so far unexperienced dimensions. By way of illustration let us refer to an example of a six-year-old child who, having seen and heard his parents talk on the phone called his friend of his age. After telling each other what they were playing, they exchanged their ideas and discussed further ways of expanding their play. Via verbal communication with no direct presence of toys/materials or playmates they were able to exchange ideas and play under the influence of a remote playmate. All this was done with the help of a modern device.

The other example is known better but it is also of a new type. Parents' computers provide as much pleasure for a lot of children as much admiration the adults use them with. The new forms of play based on modern devices bear lots of new elements, too. One of them is the tool itself, which is not the replica of the original one used by the adults but it is the original with functions that is appropriate for the children's abilities and desire. Toys inspired by the original tools would not attract children. Once they are interested in a tool they want to use the original. Imitation of adults by using the original tool even if only within the compass of play is obviously different from playing with the replicas of adults' tools.

The more traditional and widespread forms, materials and devices of modernization have a very ambivalent effect on play especially on role-play and fantasy. While children admire some certain modern materials and tools, others have no attraction for them. On the one hand, there are modern vehicles, spaceships striving to reach the stars, on the other hand, for example, there are electric scales and cash registers that suggest less ideas for play, and provide less lasting motivation, perhaps because of the limited activities they can be used for. A range of working processes that used to encourage play has vanished from households, but at the same time the rest has maintained the interest in them. Children want to make real toast, want to mix food for real when they play guests or make a snack for themselves. The integra- 
Table 2

WHAT IS THE CHILD'S FAVOURITE PLAY AT HOME?

(based on the questionnaire for parents)

\begin{tabular}{|c|c|c|c|c|c|c|}
\hline & $\begin{array}{c}\text { Alone } \\
\text { (29 types) }\end{array}$ & $\%$ & $\begin{array}{l}\text { With other children } \\
\text { (27 types) }\end{array}$ & $\%$ & $\begin{array}{l}\text { With an adult } \\
\text { (31 types) }\end{array}$ & $\%$ \\
\hline 1. & Doll, car & 17.0 & Doll, ball & 13.0 & Board game & 20.4 \\
\hline 2. & Building game & 13.9 & Building game & 12.4 & $\mathrm{He} /$ she does not play & 10.7 \\
\hline 3. & LEGO & 10.5 & Board game & 8.8 & Visual material & 10.2 \\
\hline 4. & Visual material & 8.9 & LEGO & 7.2 & Ball, book & 7.7 \\
\hline 5. & Did not specify & 8.0 & Yes, he/she does play & 6.7 & Cards & 7.1 \\
\hline 6. & Jigsaw puzzle & 3.4 & Bike & 6.2 & Jigsaw puzzle & 4.7 \\
\hline 7. & Book, bike & 3.4 & Play in the sand & 4.7 & Reading tales & 4.2 \\
\hline 8. & Ball, animal figure & 2.5 & Jigsaw puzzle & 3.1 & Cooking equipment & 2.9 \\
\hline 9. & Doll's pram & 1.3 & $\mathrm{He} / \mathrm{she}$ does not play & 2.0 & Building blocks & 2.8 \\
\hline 10. & Cooking set & 0.9 & Domino, play in a "nook" & 1.0 & Construction game & 2.3 \\
\hline
\end{tabular}

tion of the new devices into play lends colour to the activities of children. We are only at the beginning stage of these changes, but it can be stated already that the new devices will fundamentally change the circle of traditional materials and devices involved in play. The older the children are the more they want to use real objects for their play, as it is expressed in children's wishes for play: "I would drive a real car", "I would work with grand-dad's tractor".

3. Urbanization and the spread of new technologies in agriculture have caused radical changes in the relationship between people, including children and their environment. Nature as a source of gaining experiences has lost its magic. The changes involve the most of play, too. Nature ceased to be part of children's everyday life. At the threshold of the third millennium outings are only occasional experiences for most of the children.

The main difference between the forms of play is that some originate in the novelty of a single, unique experience, while other forms come into existence through the great number of discoveries in everyday life. Unfortunately, due to the low number of encounters with nature the number of nature inspired forms of play has been minimized. In Table 1 there is no mention of such a form. The affection for animal figures ranked 8th with $2.5 \%$ in the parents' answers (Table 2) does not always originate in nature itself. Other gifts of nature: crops, fruit, seeds, parts of plants, unanimated objects of nature, or nature as a scene are not mentioned at all in play at home.

4. Changes in the economic structure have affected old trades, crafts, industries and occupations as well. They were the main sources of children's play. These changes inevitably have made their impact on the adults' interpretation of play and their needs for play. Their view on play was impregnated with their love for their occupa- 
tions to a great extent. This kind of relationship between children's play and parents' occupations has been widely known within the different social strata.

The question is bound to come up: What made the parents' occupations attractive for children? The proximity of the trades, the opportunity for following a model provided by the parents, the replicas of the adults' tools that were easy for the children to work with, and also the parents' determination to hand their trade down to their children. Respect for continuity was part of the philosophy of life of families in the past.

Each of the trades, occupations had their own special mentality, set of habits and the feeling of belonging. This is how hierarchy was shaped within the different groups (craftsmen, shepherds, etc.). Parents wanted to make their children aware of this hierarchy to the same extent as they wanted to deepen the love and knowledge of their trades. The love for trades should be emphasized here because there were hardly any craftsmen who were not proud of their trades and who did not endeavour to hand down their trade-consciousness even to their very young children by creating the conditions for play that was connected with the trades.

The sweeping changes in the society led to the broadening of people's minds. The realization of the opportunity for a different life style shattered the faith in the traditional way of life not only of the adults but that of the children as well, whose new needs were formed, too, due to the new sources of experiences. The media and the widespread tourism formed new demands and broke the old sets of values, the old way of thinking, the old aims and the children's old needs for play.

The shaping of play was determined by factors different from the factors mentioned above. Within the given structure of the society nearly identical sets of values, habits prevailed, where similar objects and technical devices influenced everyday life (e. g. transport, shopping). These factors formed the ties between children's play at preschool, at the playgrounds and the yards of families. The grounds in small settlements used for play were ideal places for younger and older children alike, where older children could take care of their younger siblings and play at the same time. Due to the continuous rearrangements in the society the grounds for play decreased in number and size along with the range of play ideas, and certain types of play have disappeared. The man-made playgrounds designed instead of the old grounds can serve their purpose just partially. Primarily, because they are designed almost exclusively for physical movement, secondly, because children's sets of values and level of education received in their homes are different, and also because playgrounds have become meeting-places for different age groups with different needs that cannot be met without disturbing one another. The activities of people once living under more balanced conditions were regulated by shared values and norms. This is why children were able to come to agreements with one another easily and find common grounds in their quarrels, and this is why they could often be together without the adults' supervision. Another reason for this was also the fact that they spent quite a lot of time playing outdoors having endless territory for their games.

5. Major changes have been taking place in the habits of families. These changes have had and also have a counteractive influence on children's play. We have to add 
that this influence has been mostly unfavourable. Let us consider them from the point of view of play.

Facts show it unambiguously that families tend to become more and more introverted. Family programmes connected with social events have dropped in number. There are less family gatherings either to meet friends or celebrate important events of family members and red letter days.

Everyday habits in the families have changed. Time spent together and occasions for being together have decreased. Having meals and conversations together, working together are less determining factors in family life. Even TV programmes watched together cannot unite the members of the family. We should speak about a group of people just sitting together, instead. Even the children's questions about the less understandable parts of the programme may disturb the parents.

Family traditions related to days off that were meant to enhance togetherness are vanishing. Looking forward to the days off and Sundays used to create quite a special atmosphere in family life. Saturdays used to mean the preparation for Sundays. Days off rich in content and ideas were very different from the everyday routine. Even non-religious people respected and celebrated Sundays with rest, letting the family members have an opportunity to pay attention to one another. It was on Sundays when the relaxed and specific forms of play of the children appeared and as for the parents it was the day to make toys. It is the warmness of such a day and its special atmosphere that are missing from many children's life today.

Folk traditions of smaller communities have become poorer. Traditional gatherings such as wedding receptions held in big tents, fairs and celebrations of red-letter days, pig killing, etc. are less and less frequent. Preparation for these events involved basically everyone in the community and the experiences related to these celebrations were reflected in children's play. There is almost nothing to replace these events: wedding receptions held in restaurants are not very suitable sources for play ideas except for the bride's outfit. There is no collective preparation, no common expectation and hustle and bustle around the house and no place set up especially for the wedding reception. Other sources for play ideas show a similar pattern.

Another device determining children's - and also adults' - home activities is the $\mathrm{TV}$, which deserves special attention. In this chapter mention will be made of its role in influencing children's home habits and the changes of their activities triggered by watching TV. (We separate another chapter for the discussion of its content and its educational consequences.)

In the technical literature in Hungary and abroad children's TV watching habits are dealt with quite thorough care. ${ }^{1}$ We can read about the effects of television on children's play in Table 2 . The themes and ideas for play mentioned by the boys and ranked at the first places are obviously originated in television programmes. 13 out of the 25 ideas mentioned are related to TV (including VCR). In the girls' answers the relationship is not that shouting but in the case of some ideas the influence of

${ }^{1}$ LelKes (1994); VAJdA (1994); PlatTNER (1995). 
Table 3

WHAT WOULD YOU PLAY IF YOU COULD, IF YOU WERE ALLOWED TO? (based on children's answers)

\begin{tabular}{|c|c|c|c|}
\hline$\%$ & Boys & $\%$ & Girls \\
\hline 10.60 & play war, soldiers, shooting game & 9.16 & play with a doll, Barbie \\
\hline 5.60 & build & 6.70 & visual activity \\
\hline 5.00 & play police & 3.00 & play at being mum \\
\hline 2.80 & $\begin{array}{l}\text { play Batman, play with robots, trans- } \\
\text { formers, climb a tree, play with board game }\end{array}$ & 2.40 & $\begin{array}{l}\text { ride a big bike, play with LEGO and } \\
\text { water, splash with water }\end{array}$ \\
\hline 2.20 & $\begin{array}{l}\text { play car race, drive a battery operated big } \\
\text { car, play with an airplane, ride a bike } \\
\text { on the road }\end{array}$ & 1.80 & $\begin{array}{l}\text { sew, play with a car and board game, have } \\
\text { a doll's dinner-party, watch TV and video, } \\
\text { play at being queen, travel by train } \\
\text { play hairdressers, pay at ponies, play school, } \\
\text { climb high, climb a tree, play with a sword, } \\
\text { swing, play with a real animal, play on the } \\
\text { computer, run about, build, play and } \\
\text { perform with puppets, play a musical } \\
\text { instrument, I am allowed to play anything }\end{array}$ \\
\hline 1.60 & play zoo, fight, read books & & \\
\hline 1.10 & $\begin{array}{l}\text { watch TV, video, play with a real animal, } \\
\text { build with bricks, wrestle, play Zorro, play } \\
\text { with a train, look at books } \\
\text { I would not play }\end{array}$ & & \\
\hline 30.10 & chosen only once & 28.65 & chosen only once \\
\hline 12.30 & $\begin{array}{l}\text { he/she does not understand, does not } \\
\text { know, does not say, no such play }\end{array}$ & 14.00 & he/she does not specify, no such play \\
\hline
\end{tabular}

TV programmes can be traced back. When they say "I would ride a car" or "I'd play queen" or "I'd play with a Barbie doll" they refer to certain television programmes. In our survey we could notice some other influences of television in children's play patterns. On the one hand, we noticed the considerably small number of play themes, on the other hand, we saw a relative regularity of some games. This counteractive tendency can be explained by the big variety of TV programmes and the repetition of certain themes. The stabilization of the different forms of play is also influenced by the quick reaction of the toy-trade to the children's concrete demands. It is a fact, however, that $30 \%$ of the toys selected by the children appeared only once on the list of toys (Table 3). Now if we compare all the themes of play with the time of play available during the two weeks of the survey we can see that the data referring to a relatively short time of play given by other experts are verified. Accordingly, television programmes of particularly negative effects do not only influence the development of the child unfavourably but they have a certain strong impact on the increase of the child's passivity as well. There are television experiences that get stored up unprocessed in the child's mind causing aggression and frustrated 
Table 4

WHAT KIND OF TOY WOULD YOU LIKE TO RECEIVE?

(Ranked by children's answers)

\begin{tabular}{cll}
\hline Ranking & \multicolumn{1}{c}{ Boys } & \multicolumn{1}{c}{ Girls } \\
\hline & Vehicle & Doll \\
1. & Weapon & Barbie house \\
2. & LEGO, LEGO castle, robot & Kewin \\
3. & Robot, transformers & Doll's pram \\
4. & Clothes, action figure, motorbike & Animal figure \\
5. & Animal figure (exotic) & LEGO \\
6. & Video game and film & Bike, BMX bike \\
7. & 56 types & \multirow{2}{*}{40 types } \\
Total & & \\
& &
\end{tabular}

behaviour. The answers of a few children give food for thought because they apostrophised the children's programme they had seen in a way as if they had been playing together with the persons taking part in the programme, that is their actual play had been replaced with their intellectual - and imaginary - empathy and emotional identification.

\section{NEW FEATURES OF TOYS}

1. There are more and more toys that cross the borders of countries being unrelated to regions. The international character of toys is becoming stronger in a great part due to the media. You can find the human and animal figures of colourful children's magazines, as well as the figures known from television among the popular toys. This is so because the toy-trade ensures the appearance of fashionable toys on the market on an international scale, too.

However, two points should be made here:

a. To be correct we should add that the children's programmes of foreign origin are not the only programmes that appear on the television screen. There are Hungarian programmes as well. Unfortunately, the children specified quite a lot of toys of foreign origin in answer to the question: "What toy would you like to receive." (Table 4). These answers of children are supported by the experiences of preschool teachers as well. The answers of preschool teachers concerning the changes in children's play reflect reality today truly even if a few possible subjective opinions may occur (Appendix 1).

b. The influence of toys of foreign origin is strengthened by the toy-trade through other channels than the media, too, mainly by its adjusting the quality of toys, accessories, equipment (tin soldiers, postal equipment, trams, etc.) to the standard of the country of their origin. We can only make one objection to these toys and 
play materials, namely that there are no similar real buildings, soldiers or trams, etc. in the children's environment.

In intentionally created situations we investigated the relation between the traditional and the new fashionable toys. The survey was carried out by means of puppets. The question was to find out how attractive the puppets with new meanings are in comparison with the traditional puppets. The puppets were divided into two groups with two subgroups in each: human and animal figures (a dinosaur figure, a Donald Duck, a hippopotamus, a Barbie doll, a G. I. action figure, a transformer).

The children were allowed to select Hungarian and foreign puppets alike. 86\% of the boys involved in the survey selected foreign puppets at the first place and the Barbie doll took the palm with the girls. The proportion changed after the preschool teachers had performed a few scenes of tales with the puppets. The choice of the tales was left to the preschool teachers and our only request was to include puppets in the tales. Later when the play situation was repeated the characters from Hungarian tales were given more preference. About $43 \%$ of the children preferred the animals of native regions but only in the preschool. When the parents took these puppets home and made them available for the children the popularity of these characters from tales decreased again.

We had a similar experience in a Danish preschool in Nykobing. The group of the preschool we visited had been to a toyshop beforehand. All members of the group were allowed to select a favourite toy freely. Replicas of dinosaur skeletons and also Viking figures were on sale. At present the children have a box of dinosaurs at their disposal in their preschool. Nearly all the children returned to the preschool with dinosaurs. After a while all the dinosaurs were found among the regular toys. We did not see anybody starting play with dinosaurs. Though we saw some dinosaurs in the hands of a few children they were not attached to any play content. This example also supports the strengthening of the international character of new toys. This example is particularly revealing because it verifies very truly the statement that children do not know what to do with toys which have no roots and which cannot be connected with any acceptable events. Children's imagination gets stuck at the gate of curiosity.

2. On the basis of the questionnaires and our own observation the lack of continuity can be stated unambiguously with regard to certain types of play; on the one hand, because the recalling of certain play themes is possible only with the help of adults and, on the other hand, because certain types of play have not been characteristic of any era so far.

We can raise the question why it is important to speak about the lack of the types of play belonging to bygone times and why we should insist on their recalling. Children's getting close to nature, their discovery of nature, their understanding of the world of tales, their creating individual products are all necessary requirements for the development of the children's world that cannot exist without the most appropriate conditions necessary for this aim. This aim can be achieved exactly with the help of the mentioned types of play. The new toys and the new types of play can 
hardly meet the requirements mentioned above because of their materials and very often their themes.

A great number of new toys may create problems because children lack the previous experiences necessary for them. Namely the toys in question are not the updated versions of well-known toys but as mentioned above they are completely new (computer games, a number of new ability developing toys, etc.). The common feature of both types is the lack of continuity, that is their absolute novelty.

In order to get the old toys closer to the children we should find out more about the experiences in connection with them (just as we tried to reveal the experiences in the case of some Hungarian and foreign toys in the survey). This is why we asked the children and also their teachers, and this is why we studied the children's play. From Table 3 and Appendix 2 it emerges that the traditional toys have lost their significance. The point is not the total turning away from nature and from the need for creating and it is not even the denial of the 'old' but the formulation of children's desire for play and their wish for play. It can be seen what themes the children are open to and what themes are needless to insist on in their traditional form. It is the preschool teacher's job to recognize them even if the problem emerges with play at home.

We can see a specific form of the lack of continuity in the case of some games with movement. The children's need for movement is a generally known fact yet the ranking of games with movement among children's wishes for play is less favourable than that of the games actually occurring on the preschool teacher's list. Another conspicuous feature is that nearly all the children's wishes are connected with objects produced in industry and not with objects found in nature.

3. We would like to deal with the most characteristic feature of social changes, i. e. the polarization of social strata and its impact on play in detail. The more differentiated the society is becoming the more differentiated the range of toys in the children's home will be. We do not consider its quantitative aspects but rather its qualitative ones. Unfortunately, there is an astonishing gap regarding these aspects with nearly all social strata which can be stated unambiguously.

Now let us consider the most typical features of differentiation. The extreme diversity of the toys comes first definitely.

On the basis of our investigations into the range of toys at home the prevalence of ready-made commercial toys can be stated as a fact. There are, however, rather big differences within this group of toys. These differences are due to economic and educational reasons and also to reasons relating to different sets of values, and the opinions on these differences are also heterogeneous. For example, the most expensive toys can be found in one home, while there are hardly any toys in another. There are even more differences as regards the expensive toys. Some parents only buy the up-to-date types of traditional toys (eg. a small size roadworthy motorbike apart from or instead of a children's bike), while other parents can only think of toys with remote control. It is not worth speaking about the educational value and exploitation of these toys. There are also parents who presented their child with a computer already. 
The differences between toys can be studied according to their themes. As regards the themes in many homes the range of toys is rather narrow. There are parents who prefer only certain toys. If, for example, we divide the toys into categories according to themes like a theme of recalling past, a theme connected with everyday events and experiences and a theme pointing to the future, these three categories will hardly be found together in one family. In relation to this it is worth-while to study the children's answers. The children's needs are shown under the entry of "Three wishes" in Tables 5 and 6 . Unfortunately, such toys as puppets and play activities, games as DIY and dramatic games are missing completely; nevertheless these toys and games are the conveyers of the past and of the experiences in connection with tales. Among other things these toys and games have the inherent possibility for making tools.

The survey provides two further interesting and invaluable data. One of them is the diversity of the answers (Tables 5 and 6). The other one is the contradiction between the answers of children and the answers of parents (Appendix 3).

4. The children's needs for play have also changed considerably in relation to role-play and tools of DIY. It means that children like the tools made with excellent craftsmanship, the best of the tools belonging to well-known play themes keeping up with the perfection of the adults' objects for everyday use, on the one hand, and changing their attitude towards the already accepted toys by integrating them into their play, on the other. The telephone play serves as a good example of this. As telephone is becoming an everyday device in the life of families the telephone set will remain increasingly the toy of younger children. The older children regard the telephone as the device of actual communication with people who are not present and not as an individual toy (See the above example in relation to the telephone).

The experiences with DIY and the urge for that can hardly be demonstrated. As parents' need for DIY decreases and the content of DIY changes, DIY will lose its importance in the life of children in the same way. The repairs of electrical appliances cause the most troubles in households in which the children are not involved and the repairs are not always done at home. If any DIY is done at home, it is confined to glueing and cutting paper primarily.

5. The influence of adults on play at home has changed and is changing currently. Now we refer to three correlations only.

a. The traditional share of roles of parents at home is changing gradually. It does not only mean (and not primarily) that the father does housework according to a feminine role but it means the changes in the feminine role as well that the children experience. Because of the absence of the father, the mother is obliged to make the minor repairs and solve problems with operation of appliances on her own in a motorized household. Activities that children used to connect with father now cannot be regarded as activities belonging definitely to one certain sex role.

b. The other correlation is connected with modern toys. The influence of modern devices is stronger than that of the adults operating them. One of the reasons may be that the child concentrates on the technics, and the operation itself holds his 
Table 5

THREE WISHES FOR PLAY/TOYS

Boys

LEGO

$3 . \quad$ Weapon

4. Animal figure

$5 . \quad$ Robot

$6 . \quad$ Battery operated vehicle, vehicle with remote control

$7 . \quad$ Unrealistic toy figures

$8 . \quad$ Real motor bike, car

9. TV, video, video games

10. Motorway track system

Total: 59 types, $9 \%$ did not specify

\begin{tabular}{cl}
\hline 1. & Car \\
2. & LEGO \\
3. & Robot \\
4. & Weapon \\
5. & Real animal/Pet \\
6. & Animal figure \\
7. & Big bike \\
8. & Motor bike \\
9. & Motorway track system \\
10. & Visual activity \\
Total: 54 types, $12 \%$ did not specify \\
& \\
\hline 1. & Car \\
2. & Other vehicles \\
3. & Robot \\
4. & Weapon \\
5. & Motorway track system \\
6. & LEGO \\
7. & Animal figure \\
8. & Visual activity \\
9. & Unrealistic toy figures \\
10. & TV, video, computer \\
Total: 54 types, $18 \%$ did not specify \\
\end{tabular}


Table 6

THREE WISHES FOR PLAY/TOYS

Girls

$\begin{aligned} 1 . & \text { Barbie doll set } \\ 2 . & \text { Doll } \\ 3 . & \text { LEGO } \\ 4 . & \text { Visual activity } \\ 5 . & \text { Jigsaw puzzle } \\ 6 . & \text { Animal figure } \\ 7 . & \text { Doll's pram } \\ 8 . & \text { Other dolls } \\ 9 . & \text { Doll's clothes } \\ 0 . & \text { Printing set }\end{aligned}$

Total: 46 types, $13 \%$ did not specify

\begin{tabular}{cl}
\hline 1. & Barbie doll set \\
2. & Barbie car \\
3. & Doll \\
4. & Animal figure \\
5. & Doll's pram \\
6. & Visual activity \\
7. & Cooking equipment \\
8. & Kewin \\
9. & Specific programme \\
10. & Ball \\
Total: 45 types, $18 \%$ did not specify \\
& \\
\hline & \\
2. & Barbie doll \\
3. & Barbie house \\
4. & Barbie doll set \\
5. & Visual activity \\
6. & LEGO \\
7. & Kewin \\
8. & Jigsaw puzzle \\
9. & A piece of clothing (a dress $)$ \\
10. & Book \\
Total: 51 types, $24 \%$ did not specify \\
\end{tabular}


attention and the adult himself/herself is less interesting for him/her. The operation of modern toys is not originated from the parents, it is given, put down on paper. The other reason is related with the facts referred to above. When operating modern devices the child is an equal partner of the adult to a certain extent and what is more the child can very often find a way of solution more quickly. At the same time the demonstration of the operation and the handling of modern devices are not always originated from the parents either.

c. The parents' play with their children is not satisfactory in every respect: a lot of parents do not play with their children at all, especially with older children. Those who do, often play only when the occasion arises and in the case of boys it is more often confined to ballgames.

We can say, in summary, that the parents are not the primary models for children's play any more.

\section{NEW OBJECTIVES OF PRESCHOOL}

1. In order to become open to the new features represented by the toys and the forms of play a new educational attitude and new approaches are needed in preschool. The above-mentioned changes in society and play are reflected in play in the preschool in a way that is different from the way of its reflection in play at home, partly because the two scenes of play are not the same in every respect and because the two scenes do not respond to changes at the same rate and with the same sensitivity. The movements in society affect the families and the preschools in different ways, both globally and in their details.

2. The preschool as an institution will have to answer a wide range of questions that has not been asked before eg.: what can preschool undertake to meet the children's needs for play? In what ways does it try to cooperate with parents both individually and collectively? What types of play does preschool endeavour to arouse interest in?

The task of selection in relation to play is rather complex: the task of adoption, the task of addition and the task of rejection are all involved. Our answers to the questions raised above are only partial and some of them require rethinking in a while because of the above-mentioned turbulent changes. Let us consider some of these answers.

a. First of all we should be fully aware of the different experiences of the children admitted to the preschool and the different influences of these experiences. A stronger differentiation can be observed, especially from the ages of 4 to 5 .

One of the objectives of preschool is the moderation of extreme differences in relation to the sources of experiences and the interests in play and the moderation of drawbacks. The survey outlined above is very revealing in many respects. No matter how wide the range of sources of play is, it often indicates a tendency of a one-sided selection in the case of some children, children's play is often confined to the domain of either modern toys/games or constructive toys/games or possibly action games. 
Consequently, it is the task of the preschool to provide the balance for the sake of the development of children. At present not even our preschools are capable of dealing with the wide range of toys.

b. The everyday task of preschool is to provide the adequate proportion of solitary and collective forms of play based on experiences of today and representing the future, as well as for the forms of play initiated by either the children or the preschool teachers. Nowadays the proportions can be rather accidental and ideawise or even asymmetrical yet. For the time being we have few data referring to them.

3. Similarly, the great number of visual experiences and information are a new and determinant feature. If the data referring to children are homogeneous in any way it is due to the influences of the electrical media. The parents as we have seen are not able to find the best solutions in this respect. It is the task of the preschool to face this fact. It is within the competence of the educational institutions to ensure the conditions needed to prevent the passive reception of the experiences with the media and to encourage children's activities. The children are not capable of integrating into their image of world the events that excite a lot of tension and are often pictured in a naturalistic way without their personality getting hurt. As a matter of fact, the preschool has the most self-evident opportunity for this rather complicated process of the easing of tension, that is for play which is an activity embedded in actions, joined with other different actions and built on more and more complicated actions. We should be well aware of some new circumstances exciting tension that involve the child's internal need to release tension through play. It is by no means an easy but an important task of the preschool to provide the favourable conditions for this.

a. Preschools are not prepared yet to handle the tension of a new type and of a rather stronger influence. The experiences and traditions accumulated for centuries do not always put us on the right road. Traditionally, our concept of play has helped us ease seemingly very simple types of tension, for example, tension arising from the appearance of Santa Claus or the sight of a drunken person. Non-recurring and relatively not too deep impressions require different methods of handling from the methods necessary in the case of more complicated and nearly always present impressions. New pedagogical approaches, a wide social collaboration and a new psychological culture are the necessary requirements.

b. Tension is often excited by the preschool, too, when the preschool cannot provide new free-time activities, but, of course, this kind of tension is not similar to the kind mentioned above. The everyday routine can cause boredom and dejection and it soon brings to the surface the hidden tension stored inside and the irritability of an increased degree. Toys can be suitable for either easing or exciting tension. Toys can only affect children soothingly if they awaken positive feelings and at the same time they can hold the children's attention. When providing toys it is to be wished that the range of toys should be designed according to the children's actual desire and need for play even if the educational value of some toys is sometimes controversial. 
Table 7

CHILDREN'S FAVOURITE TOYS

(ranked by children's answers)

\begin{tabular}{crlrl}
\hline Ranking & \multicolumn{2}{c}{ Boys } & \multicolumn{2}{c}{ Girls } \\
\hline & & & & \\
1. & 34 types & vehicle & 25 types & Barbie doll \\
2. & 28 types & vehicle & 17 types & animal figure \\
3. & 20 types & vehicle, LEGO & 10 types & animal figure \\
4. & 7 types & matchbox & 3 types & ball \\
\hline
\end{tabular}

TOYS/MATERIALS NECESSARY FOR CHILDREN'S FAVOURITE PLAY ACTIVITIES

\begin{tabular}{lll}
\hline Number & \multicolumn{1}{c}{ Boys } & Girls \\
\hline & & \\
1. & Vehicle: car, dumper, crane, lorry, tran, motor bike & Doll, Barbie doll \\
2. & LEGO & Doll's clothes \\
3. & Weapon: guns with cartridge, telescope, laser & Animal figure \\
4. & Robot & Construction toy \\
5. & Animal figure & Jigsaw puzzle \\
6. & Ball-football & Visual materials \\
& & \\
\hline
\end{tabular}

Children often behave aggressively towards toys in their possession by the mere fact that toys do not have inspiring powers. We can recommend the withdrawal of all the toys from the preschool group that nobody is interested in or the interest in them is just minimal. It can happen that we should get rid of toys which have been popular for decades.

c. At present there is a huge gap between the adults' wishes in relation to play and the children's needs for play. The preschool teachers are not prepared to deal with the big social changes they were snowed with. Similarly, they are also at a loss as regards a few new needs for play. Tables $1 / \mathrm{a}, 1 / \mathrm{b}, 5,6$ and 7, Appendices 3 and 4 demonstrate clearly the weak points of play-communication between the persons concerned. It is conspicuous that the children's answers are different from the answers of the adults - parents, preschool teachers - in more than one respect. A great number of children specified "the computer", "the real motorbike and car", "real cooking", "bathing a real baby" as their wishes for play. The word "real" means the affirmation of the adults' working tools, equipment and objects in contrast with "just" toys. consequently, the toy tools and the working tools appear in a natural complexity. The new feature of the children's imagination is the simultaneous appearance of play and work, partly because some of the working tools are very appropriate to enrich their world of play. At the same time, however, you cannot imagine the operation of household and other appliances by means of "toy tools". Evident proofs of this need can be observed with six-year-olds which indicates the survival of role-play. 
We can see a new form of creating, a new form of "the need for creating something" the preschool should be prepared for in a new way as well. (e. g. it should make the range of devices wider with up-to-date household appliances and include the activities that can be done with them in the daily schedule of the preschool.)

d. Appendix 4 demonstrates the answers of preschool teachers related to negative toys. We think that instead of the definite rejection of toys of a negative effect we should study one by one all the widely popular toys that are not allowed at preschool. Preschools should be aware of the rearrangements in the forms of play and the changes in character and structure of the individual activities of children. The more coordinated operation of the visual stimuli and the respond to act, the increase of the desire to create, the experience of the pleasure of creating, the involvement in the creation of the material conditions, toys and materials necessary for play, the increase of the ability of cooperation, the evolvement and putting forth of abilities in problem situations will be even more natural in play. All these objectives are wellknown in professional circles but they appear to be even more increased needs because of the changes in the environment of the children. The decrease in the opportunities for play in the family involves their supplement in preschool as a consequence.

4. The creation of the necessary conditions for integrating the new emerging experiences takes place according to another kind of principle that is different from the principle in the case of the continuous and regular experiences. Play can feed on both kinds of experience but their motivation benefits are different. In play drawing on experiences not the same points are stressed in all cases. It applies equally to play of which source of experience the child has already left and to play that requires room as a new element in the system of the play of the child. Consequently, we cannot deal with the world of experiences of bygone times in the same way as we do with events present continuously. All preschool teachers are aware of this rule but we all should seek better solutions that are more adjustable to the child in order to be able to emphasize it in everyday practice for the very reason of its novelty. At the same time this adjustment to the new circumstances requires the modification of the internal systematic rearrangement, the internal structure, the system of conditions of the preschool and also the rethinking of objectives.

5. The creation of new conditions for play in preschool means that apart from providing conditions for free play the varied engagement of the preschool teacher in play should also be provided. Solitary play, cooperative play with peers and adults can be justified on condition that they do not overburden the child, provide for the complete freedom of the child and they are not subordinated to any intentions forced upon the child.

Under these conditions only can we state that children's play will point to the future, drawing on the past with the pleasure of today. 


\section{APPENDIX 1}

CHANGES IN CHILDREN'S PLAY

(based on preschool teacher's answers)

Play ideas taken from video and TV films

Modern techniques and technology appear

Watching TV (and video) instead of play

More aggressive and restless children at play

Spread of martial arts games (karate, judo)

Less role-play

Dirty words in play (influence of TV, video)

Few play experiences taken from family life

Poor play ideas

Increased interest in logical games

More construction games that are richer in content

Computer games, more and more experiences with computer games

Home experiences are hard to recognize, children do not know the qualities attributed to roles

More need for physical movement

Not much stamina in play

New occupations (also complexes of services) in play

Use of new, modern phrases in speech

Interest in technical themes (not enough satisfaction from ready-made commercial toys)

More board games

There would be more construction games if conditions were provided for them

Children like to implement their own individual ideas

Need for TV and VCR

Content of play has changed

Scary animal roles in role-play

Due to multiple rearrangements in the social structure hard to stabilize a system of rules and habits and create a well-established atmosphere

Need for handicraft

Computer games at home take the place of classical play

Unrealistic elements - influence of science fiction

Spooky stories

Older preschool children prefer board games, games with more distinctive rules and jigsaw puzzles

Less time spent with active play!

Traditional types of play have lost their significance 
APPENDIX 2

WHAT WOULD YOU PLAY IF YOU COULD, IF YOU WERE ALLOWED TO?

Boys

I would play with a puff-puff, with a remote conrol train.

I would always be outside.

I would roll a car wheel.

I would play with a car but it makes a noise and so it is not allowed too often.

I would ride a motor bike but there is no petrol in it.

I would play with a German shepherd dog but it is not allowed because it might bite me.

I would play with a LEGO police system but I don't have one.

I would play soldiers but I don't have many soldiers.

I would play on the computer if there was one in the preschool.

I would buy a computer.

I would do karate and drive a real car.

I would step into mud.

I would dig very deep.

I would mess about.

I would play soldiers, I would make a hell of a big mess and play divers, too.

I would drive and fix my dad's car.

I would work with my grand-dad's tractor and transport tomatoes.

I would like to have a look at what there is in the attic.

I would like to play what I can't yet.

I would play poker but I don't know how to play it.
Girls

I would glue feathers together and make wings.

I would put on my mum's clothes.

I would paint the walls of my room.

I would can fruit at home.

I would always be in the school-yard and play at the back where nobody can see me.

I would play with my mum's jigsaw puzzle of 101 pieces

I would bounce on the bed and on the table.

I would dump the clothes to the floor.

I would feed a real baby. I would play at being mum with a real baby. I would bath my little sister/ brother. I would play at having guests with real juice. I would give the baby real cocoa to drink and do real cooking.

I would play with a wind-up toy but my mum doesn't allow it because I would break it.

I would watch video but my dad doesn't allow it.

I would break the doll's leg.

I would play with a Barbie doll but I don't have one.

I would play with a baby doll if I had one at home.

I would push a doll with sleeping eyes in a pram but I have neither a doll nor a pram.

I would put lipstick on my lips and varnish my nails. 
APPENDIX 3

CHILDREN'S NEEDS FOR PLAY THAT PRESCHOOL TEACHERS ARE UNWILLING TO MEET (based on preschool teachers' answers)

tools, materials provoking aggression

rifle, handcuffs, gun, sword

Barbie doll

monsters

battery operated toys

robot

video film

playing soldiers and ninjas

cars with balance-wheels

model clay

small beads (for young children)

modern toys making children aggressive

"destroyer" car

karate

\section{LEGO pirate}

ghost castle

transformers

electric car

action figures

pony

teenage mutant hero turtles

battery operated cars

Batman

Zorro

vulgar plastic toys

Dino

video games

APPENDIX 4

CHILDREN'S NEEDS FOR PLAY THAT CANNOT BE MET

(based on preschool teachers' answers)

computer games, games software

LEGO, DUPLO

outdoor action games

electronic toys

does not specify

robot

mosaics

train, car with table to play on

BMX bike

gym equipment

toys with remote control

video games

no unmet need for play

modern expensive toys

replicas with table for their display

theme table for wild and domestic

animal figures

DIY from natural materials

cooking from real ingredients

plastic cutlery

medical kit

hairdresser's kit

toys developing sensation, perception bodyroll

technical toys

doll's pram

motorbike

town

port

airplane

spaceship

ASCO and DISCOVERY products

metal construction game

cartridge gun

horse game

spinning-top

a variety of materials for role play

quality play dough

battery operated car

skateboard

scooter

DIY kit

toys from TV commercials

sewing, weaving, trimming, cutting

bigger space for play 


\section{LITERATURE}

KOMLÓSI, Sándor (ed.)

1995: Családi életre nevelés. (Education for family life.) Budapest. Nemzeti Tankönyvkiadó.

KovÁCs, György-BAKOSI, Éva

1995: Játék az óvodában. (Play in the preschool.) Debrecen.

LELKES, Éva

1994: Én így tanítok. (I teach this way.) Szolnok.

PLATTNER, Elisabeth

1995: A nevelés mindennapi múvészete. (Everyday art of education.) Budapest.

VAJDA, Zsuzsanna

1994: Nevelés, pszichológia, kultúra. (Education, psychology, culture.) Budapest. Dinasztia Kiadó. 